sciendo Порівняльна професійна педагогіка 9(1)/2019 Comparative Professional Pedagogy 9(1)/2019

DOI: $10.2478 /$ rpp-2019-0010

Intern at Regional Institute of Social Work Aquitaine, Bordeaux (France), SERGIY YASHCHUK National University of Life and Environmental Sciences of Ukraine Address: 16-a Heroiv Oborony St, Kyiv, 03041, Ukraine E-mail: sergiolife92@gmail.com

\title{
ORGANIZING THE EDUCATION PROCESS IN FRANCE: THE EXPERIENCE OF REGIONAL INSTITUTE OF SOCIAL WORK AQUITAINE, BORDEAUX
}

\begin{abstract}
The article analyzes the stages of organizing the education process in social schools in France based on the example of Regional Institute of Social Work Aquitaine, Bordeaux. It is found that the Institute pays specific attention to the basic courses: professionalization and methodology; social and solidarity economy; professional approach to service; social connections and exclusion; legal approaches; project development and management; sociology of education; human development; psychopedagogy of animation project; family law; social protection and social security; research methodology; legal approach to information management for the EU countries; humour and pedagogy; oral communication and education; anthropology of education; education and philosophy, the views on the education process: family education; mental disability: history and current events; self-study and lifelong learning; psychology of education: theoretical principles, methods, educational and social practices. It is clarified that the main characteristic of social careers in France, regardless of specialization, is the ability to provide permissive and appropriate mediation between the individual, family and society, state and social structures; to act as a partner, linking the personality and society, children and adults, family and society. It is justified that there is no distinction between "social worker" and "social educator" in France. French specialists consider social work to be "personal support services for people", which is based on certain sciences (law, psychology, sociology) and accumulated experience of practical sociopsychological, health-improving, rehabilitational and therapeutic support of the individual.

Keywords: social work, organization, social worker, professional orientation, rehabilitation, project, internship, legal approach.

\footnotetext{
АНОТАЦІЯ

Проаналізовано етапи організаџії освітнього прочесу у сочіальних школах Франиії на прикладі сочіальної школи l'IRTS м. Бордо. Визначено, щу увага у сочіальній школі акцентована на основних дисииплінах: професіоналізація та методологія; сочіальна та солідарна економіка; професійний підхід до обслуговування; сочіальні зв'язки та виключення; правові підходи; професійний підхід до обслуговування; розробка та управління проектами; сочіологія освіти; розвиток людини; психопедагогіка анімаційного проекту; сімейне право; сочіальний захист і сочіальне забезпечення; методологія дослідження; професіоналізація та методологія; правовий підхід до управління інформачією для країн СС; гумор і педагогіка; усна мова і освіта; антропологія освіти; освіта та філософія, мислення освітнього процесу: приклад сімейного виховання;
} 
sciendo Порівняльна професійна педагогіка 9(1)/2019 Comparative Professional Pedagogy 9(1)/2019

психічна непрачездатність: історія та сучасні подї̈; самонавчання та навчання протягом усього життя; психологія освіти: теоретичні основи, методи, освітні та соиіальні практики. 3'ясовано, щзо основною характеристикою професій «соціальної кар 'єри» у Франиії, незалежно від профілю і спеціалізації, є здатність забезпечувати допустиме й доречне посередництво між особистістю, сім'єю і суспільством, держсавними та суспільними структурами; виконувати роль партнера, зв'язуючої ланки між особистістю і соиіумом; між дітьми і дорослими, сім'єю і суспільством. Обгрунтовано, що у Франції, не має розмежування «сочіальний працівник» $i$ «сочіальний педагог. Сочіальна робота розглядається французькими фахівиями як «особистісна служба допомоги людям», щуо у своєму розвитку спирається на певну сукупність наук (правознавство, психологію, сочіологію) і накопичений досвід практичної сочіально-психологічної, медикооздоровчої, реабілітаційно-терапевтичної підтримки особистості.

Ключові слова: сочіальна робота, організачуія, сочіальний працівник, професійна орієнтація, реабілітаџія, проект, стажування, правовий підхід.

\section{INTRODUCTION}

The hierarchy of social workers' work values differs from that of other specialists in several particularly significant indicators such as altruism, freedom, lifestyle, social interaction and a material factor (Yashchuk, 2016). Consequently, there are two functional concepts, in particular, the idea of professionalism and respect for human rights (Yashchuk, 2012, pp. 21-22). Some specialists single out three ways of evaluating teaching competency: profound knowledge of the subject, skills and skills in teaching it and identifying the qualitative level of students' and educators' knowledge; an attitude to the subject and the chosen profession, teaching experience (Zhuravska, 2015, pp. 11-15; Zhuravska, 2006, pp. 15-18); the ethics of communication with students and colleagues, knowledge of the latest technologies and world scientific achievements.

\section{THE AIM OF THE STUDY}

The research aims to analyze the stages of organizing the education process in social schools in France based on the example of Regional Institute of Social Work Aquitaine, Bordeaux (France).

\section{THEORETICAL FRAMEWORK AND RESEARCH METHODS}

Such scholars as L. César-Franquet, S. Kubitskyi, Y. Meunier, S. Nikolaienko, L. Viktorova studied the characteristics of social workers' professional training. The researchers on legal competence of specialists were conducted by P. Camille, M. Sherman, V. Shynkaruk, L. Veronique, S. Yashchuk et al.

In order to achieve the aim of the study, the following research methods were used: analysis and generalization of empirical and theoretical principles contained in professional and reference literature on various scientific fields (pedagogy, psychology, sociology, law, teaching methodologies, social work, etc.), as well as in the works by Ukrainian and foreign researchers.

\section{RESULTS}

The entire team of Regional Institute of Social Work Aquitaine, Bordeaux (France) congratulated 90 interns on the beginning of the 2018-2019 academic year: Yves Meunier, head of the centre for initial training; Laetitia César-Franquet, an educational manager; Aurélie Le Duff, head of the center for partnership, internship and training. The leaders of the Institute motivated the interns towards volunteer professional orientation aimed at 
informing the public about "The Professional Stand" of the Institute: "Regional Institute of Social Work Aquitaine, will participate in various trade fairs of professional orientation (January 11, 12 and 13, 2019 - secondary school; February 8 and 9, 2019 - the student job fair in the Aquitec Exhibition Center, hall 1 - Bordeaux-Lac) (l'RTS, 2018).

Educational manager L. Cesar-Franco provided the interns with information about the timetable of classes for the current academic year. Thus, classes are scheduled from 8 $30 \mathrm{am}$ to $5 \mathrm{pm}$ from Monday to Friday. In addition, the volunteer internship in orphanages for children, adults and people with special needs is scheduled for April, 2019; pre-diploma practice - for February-June, 2019 (l'RTS, 2018).

The interns got acquainted with professors of the Institute. The main attention was paid to the courses they teach, namely, Edith Montmoulinet - professionalism and methodology; Denis Decourchelle and Sante Modus - social and solidarity economics; Florence Aurort Lutard and Geraldine Duhalem - professional approaches to services; Blandine Dault - social connections and exclusion; Camille Pellicer - legal approaches; Fabien Clouse - project development and management; Xavier Lacombe and Mélina Eloi sociology of education; Veronique Lascaut - family law; Michael Vacher Michael - social protection and security; Michelle Ferriere - oral communication and education; Eric Lucy education and philosophy; Eric Monnier - humour and pedagogy; Dominique Millet anthropology of education; Julie Pinsolle - the views on the education process: family education; Florence Brumaud - mental disability: history and current events; Fabien Dousse - self-study and lifelong learning; Julien Curt - psychology of education: theoretical principles, methods, educational and social practices (l'RTS, 2018).

At the meeting with the leaders of the Institute, professors delivered their speeches. M. Eloi, a postdoctoral researcher of sociological sciences, emphasizes that the course on Sociology of Education covers three important components. The course primarily focuses on classical studies and authors of sociology of education (Durkheim, Bourdieu, Boudon, Rosenthal, Jacobson et al.), as well as education democratization (social origin and success at school, gender and educational success, educational policy and social inequality of success, etc.) (Merlier, 2013). Finally, the interns are expected to study sociological studies (atypical success or failure at school, school work, school violence, etc.). As for the methodology of the course, it includes training sessions, lectures and work on the documents (articles and statistical tables) and presentation of one's views on the latest sociological studies and problems. The assessment of the course involves both oral and written work, including presentations and projects. It is possible to retake the course.

M. Ferriere, a social worker and postdoctoral researcher of social sciences, teaches the course on Oral Communication and Education. The researcher notes that well-bred speech is not innate but constructed. As evidenced by relevant studies, a child who learns well has well-bred speech. The scholar highlights the importance of how important education is (Brugere, 2011). He emphasizes that the subject of courses on education, pedagogy, psychology, sociology is speech. The methodology of the course includes group work focusing on case studies (educational situations; therapeutic place; speech as a mediator through history, language and youth). The assessment of the course involves the following: everyone chooses a topic related to oral or written speech. After that, the interns exchange opinions and formulate questions which contribute to developing the chosen topic. They also exemplify theoretical concepts and bibliographic references. The examples can include written or spoken situations found on the sites of case studies. Each intern must 
prepare a personal written project, at least five pages on the chosen subject. This written work will become the subject of an oral presentation to the group.

D. Decourchelle, a postdoctoral researcher in ethnology and counsellor, emphasizes the importance of the course on Ethnology and Disability Pedagogy. He indicates that the topics covered in the course are related to different contexts of disability and views on health: historical approach to classification and social support (Bouquet, 2012); cultural approach (norm, deviation, ugliness); an institutional way of life (dependence, closeness and community). It is stated that the views on health concern the ways of interpreting the disease and the body, in parallel with "rational" medicine. The researcher also mentions various models proposed by ethnology (anthropology of health). The interns are offered to focus on one of the models of ethnology and thus determine the disability or disease of the individual, as well as interview him/her during the internship. The methodology of the course implies that the course should be a kind of exchange between interns during seminars and cooperative activities during which proposals and hypotheses are the subject of discussion. Lectures are accompanied by the bibliography. The assessment of the course includes writing essays on a particular issue, establishing and interpreting the interview.

E. Lucy, a postdoctoral researcher of education and a social educator, pays considerable attention to the course on Education and Philosophy. In the context of ethical legal and political issues, educational and social work refer to philosophical views. The scholar suggests that the interns should reflect on some of the issues related to philosophy. He highlights the training modes incorporated into the course, namely literary texts and case studies, as well as cooperation in the context of norms, relations of power, social control and ethics (Boyer, 2011). This work can also be a preparation for writing a personal essay on the knowledge and skills gained during the internship. The methodology of the course includes lectures, debates and oral presentations and the assessment - oral and written projects.

The course on Humour and Pedagogy allows the interns to form their professional identity dealing with the heritage of the prominent educators and drawing on the crosssectional analysis of educational practices. Studying Jean Houssaye's works, one can understand the mixed and clearly formulated overview of pedagogical trends. P. Ladriere (1991) indicates that the educator Jean Houssaye is the one who seeks to combine theory and practice with his own actions. However, the views on humour can make one think about the ability to realize one's educational activities. P. Guillot explains the concept of "humour and pedagogy" as follows: humour is not just a free game but a pedagogical relation of relativization (the rejection of an absolute value). Humour combines clarity and playfulness: it refers to the poetics of understanding. The methodology of the course includes coverage of field issues; discussions on practical activities; exchange of works in connection with the relevant issues, referring to the ideas of the prominent educators; crossreading of literary, philosophical, poetic, humorous texts. The assessment of the course involves oral and written presentations. If necessary, the interns can retake the course.

D. Millet, an associate professor of philosophy, teaches the course on Anthropology of Education. He asked the interns the following questions: Is education a characteristic of the human species?; How to become human?; What part of human behaviour comes from the innate?; What is transmitted during training? etc. He also indicates that these questions, asked by anthropologists, allow one to look at educational practices in human societies. Oppositional nature/culture developed by Claude Lévi-Strauss will structurize the 
8 sciendo Порівняльна професійна педагогіка 9(1)/2019 Comparative Professional Pedagogy 9(1)/2019

reflections on the place of education in our societies and other social groups, in the search for the universal and the personal. He states that the course addresses the issues of people who must change cultural links through migration. It is necessary to question the conditions of intercultural or multicultural education. The methodology of the course includes reading and analyzing the main texts, argued discussions and theoretical contributions, alternating with educational practices. The assessment of the course implies that each intern should write a brief essay on the chosen topic preliminary approved by the course lecturer.

The course on the Views on the Education Process: Family Education aims to transform the education process through studying scientific texts. Julie Pinzol, the course lecturer, indicates that this will make it possible to consider the main models of family education (the latter can be defined as daily actions performed by parents during the interaction with their children) and question the transformations children experience from these actions. In addition, these transformations can be seen in an unprecedented education process in the field (education is no longer evident and is becoming more and more problematic). Rapid transformations during the education process can be understood as the result of changes in our attitude towards childhood and the child who appears in our society as the subject and the individual. Finally, this transformation eventually becomes a formidable movement to promote "childhood in the child" since the course questions the consequences and, in particular, the emergence of new educational norms such as dialogue, trust, confidence and autonomy. The methodology of the course includes reading and discussing texts, exchanging opinions. The assessment of the course involves writing essays about the transformation of education according to individual professional projects.

The course on Psychological Disability: History and Contemporary Events allows one to understand how the concept of mental handicap is gradually reinforced in our society and transformations and how this idea promotes the connection between individuals and society. It must be noted that it also includes studying university text in order to create a critical exchange of concepts of mental disability, compensation, behavioural disorders during school education, etc. Thus, the interns are encouraged to question the concept of "mental disability" in all its dimensions (historical, sociological, and psychological) and link this knowledge with their professional practice. The methodology of the course includes reading, discussing and presenting texts. The assessment of the course involves presenting the consolidated report: theoretical contributions, texts and discussions according to an individual professional project.

The course on Self-study and Lifelong learning is based on teaching forms outside the formal structures throughout life. Self-education, as a process of self-organization, provides personalized production of knowledge to organize the links between experience and theoretical knowledge. Dealing with the unknown and interacting with a vulnerable public, a social worker should be creative, spontaneous and able to provide theoretical and practical answers. Therefore, articulation (the way of performance) is viewed as the acquisition of knowledge from the so-called "noble" and "secular" knowledge in relation to one's own experience. The methodology of the course includes discussing theoretical issues of education throughout life and providing reflexive feedback on personal experience, taking into account the importance of group work. The assessment of the course involves preparing a five-page independent work according to an individual professional project. 
The course on Psychology of Education: Theoretical Principles, Methods, Educational and Social Practices aims to describe theoretical principles of various educational and social methods and practices since social work consists of different teaching methods and practices. The genesis of these diverse approaches is often related to different concepts of human activity: disciplinary spheres, nostalgic (painful) debates, institutional choices, advisory practices, etc. The methodology of the course includes reading and discussing texts in accordance with an individual animation project. The assessment of the course includes preparing group oral presentations (critical views on a certain teaching method or practice).

The course on Detecting Conflict Experiences and Tracking Traumatic Consequences is based on the experience gained during the internship. It aims to teach the interns to collectively identify conflict experiences that can cause injury and the gap in society with the effect of the fracture. Once these "analytical cases" have been identified, the interns will be expected to counterbalance them with sociological concepts in order to define the "keys of understanding" for mobilizing in a professional environment. The methodology of the course is based on the experience faced by the interns in the workplace. To this end, they are expected to work together on various "practical cases" defined by individual professional projects. The reflections and readings of scientific articles are performed by working groups and should be discussed. The relevant conclusions should be jointly drawn. The assessment of the course involves preparing a five-page written report representing a practical case that is experimenting with internships or can be presented in perspective with the sociological concepts discussed in classes (l'IRTS, 2018).

\section{CONCLUSIONS}

Based on the analysis of scientific and reference sources, it is concluded that academic courses incorporate lectures, practical classes (project development and management, situational studies, correction of situational learning); seminars (designing stories; internship assignments, module presentations, professional practice analysis, presentation of the test on institutional dynamics, presentations of the journal of clinical research). It is found that the assessment of educational attainment involves taking professional tests, writing and defending professional projects.

The prospects for further studies include the detailed characterstics of assessment in Regional Institute of Social Work Aquitaine, Bordeaux (France).

\section{REFERENCES}

1. Bouquet, B. (2012). Ethique et Travail social, une recherche du sens. Paris: Dunod.

2. Boyer, A. (2001). Guide Philosophique pour penser le travail éducatif et médicosocial. Paris: Erès.

3. Brugere, F. (2011). L'éthique du care. Paris: PUF.

4. Ladriere, P. (1991). L'éthique, soi et les autres. Informations sociales, 9, 10-18.

5. l'IRTS. (2018). Retrieved from http://www.campus-irts.fr.

6. Merlier, P. (2013). Philosophie et éthique en travail social. Rennes: Presses de l'EHESP.

7. Yashchuk, S. P. (2012). Konstitutsionnoe i mezhdunarodnoe pravo: sovershenstvovanie osnovnogo zakona. Suchasni napriamy teoretychnykh i prykladnykh doslidzhen, $18,21-22$. 
sciendo Порівняльна професійна педагогіка 9(1)/2019 Comparative Professional Pedagogy 9(1)/2019

8. Yashchuk, S. P. (2016). Formuvannia profesiino-pravovoi kompetentnosti studentiv. Naukovyi visnyk Natsionalnoho universytetu bioresursiv i pryrodokorystuvannia Ukrainy. Seriia: Pedahohika, psykholohiia, filosofiia, 253, 333-339.

9. Zhuravska, N. S. (2006). Teoriia i metodyka profesiinoho navchannia. Kyiv: Vydavnychyi tsentr NAU.

10. Zhuravska, N. S. (2015). Metodyka navchannia ta vykhovannia u vyshchykh navchalnykh zakladakh krain Yevropeiskoho Soiuzu ta Ukrainy. Porivnialnyi aspekt. Nizhyn : Lysenko M. M. 